\title{
A Quantitative and Qualitative Study of Retail Food Waste in New Zealand ${ }^{\dagger}$
}

\author{
Sheila Skeaff ${ }^{1, *}$, Francesca Goodman-Smith ${ }^{1}$ and Miranda Mirosa ${ }^{2}$ \\ 1 Department of Human Nutrition, University of Otago, Dunedin 9054, New Zealand; \\ f.goodmansmith@gmail.com \\ 2 Department of Food Science, University of Otago, Dunedin 9054, New Zealand; \\ miranda.mirosa@otago.ac.nz \\ * Correspondence: sheila.skeaff@otago.ac.nz; Tel.: +643-479-7944. \\ + Presented at the 2018 Nutrition Society of New Zealand Annual Conference, Auckland, New Zealand, \\ 28-30 November 2018.
}

Published: 7 March 2019

Background: An estimated one-third of the global food supply is wasted. Measurement of food waste, at each step of the food supply chain, is necessary in understanding the scale of the problem and to identify areas for intervention. The aim of this study was to measure the quantity of retail food waste in NZ, and to identify key motivators and barriers to retail food waste reduction.

Methods: This was a quantitative and qualitative study of 16 supermarkets in four urban centres. Onsite food waste audits were carried out in both Countdown $(n=8)$ and Foodstuffs $(n=8)$ supermarkets located in Auckland, Wellington, Christchurch and Dunedin. Food waste generated over a 24-h period in each store was audited. Semi-structured interviews were carried out with key retail staff at each supermarket to identify usual waste behaviours, motivators, and barriers associated with in-store food waste reduction.

Results: Complete quantitative data was obtained from 11 of the 16 supermarkets audited. A total of $77 \%$ of all discarded food measured in onsite audits was diverted from landfill. Of the $77 \%$ of food diverted from landfill, $46 \%$ was donated for animal feed, $15 \%$ was donated to food rescue organisations, $14 \%$ was directed to protein reprocessing, and approximately $1 \%$ was composted. Of the $23 \%$ of food waste sent to landfill, $23 \%$ comprised of dairy products. Bakery, and meat and fish each contributed $21 \%$ to total landfill food waste. Estimates for retail food waste in NZ amounted to $13 \mathrm{~kg} / \mathrm{capita} /$ year for all food waste and diverted product, $5 \mathrm{~kg} / \mathrm{capita} /$ year for food waste only, and $3 \mathrm{~kg} / \mathrm{capita} /$ year for food waste sent to landfill.

Conclusions: This is the first study to measure retail food waste in NZ. Waste reduction initiatives in NZ should focus on reducing food waste at the source, as well as diverting dairy, bakery, meat, and fish away from landfill.

(C) 2019 by the authors. Licensee MDPI, Basel, Switzerland. This article is an open access article distributed under the terms and conditions of the Creative Commons Attribution (CC BY) license (http://creativecommons.org/licenses/by/4.0/). 